\title{
Penerapan Model Pembelajaran Kooperatif Group Investigasi untuk Meningkatkan Hasil Belajar dan Kemampuan Berpikir Kritis
}

\section{Pahrurrozi}

Program Studi Biologi, Universitas Nahdlatul Wathan Mataram, Jl. Kaktus No 1-3 Mataram, Indonesia

Email:occionfire@gmail.com

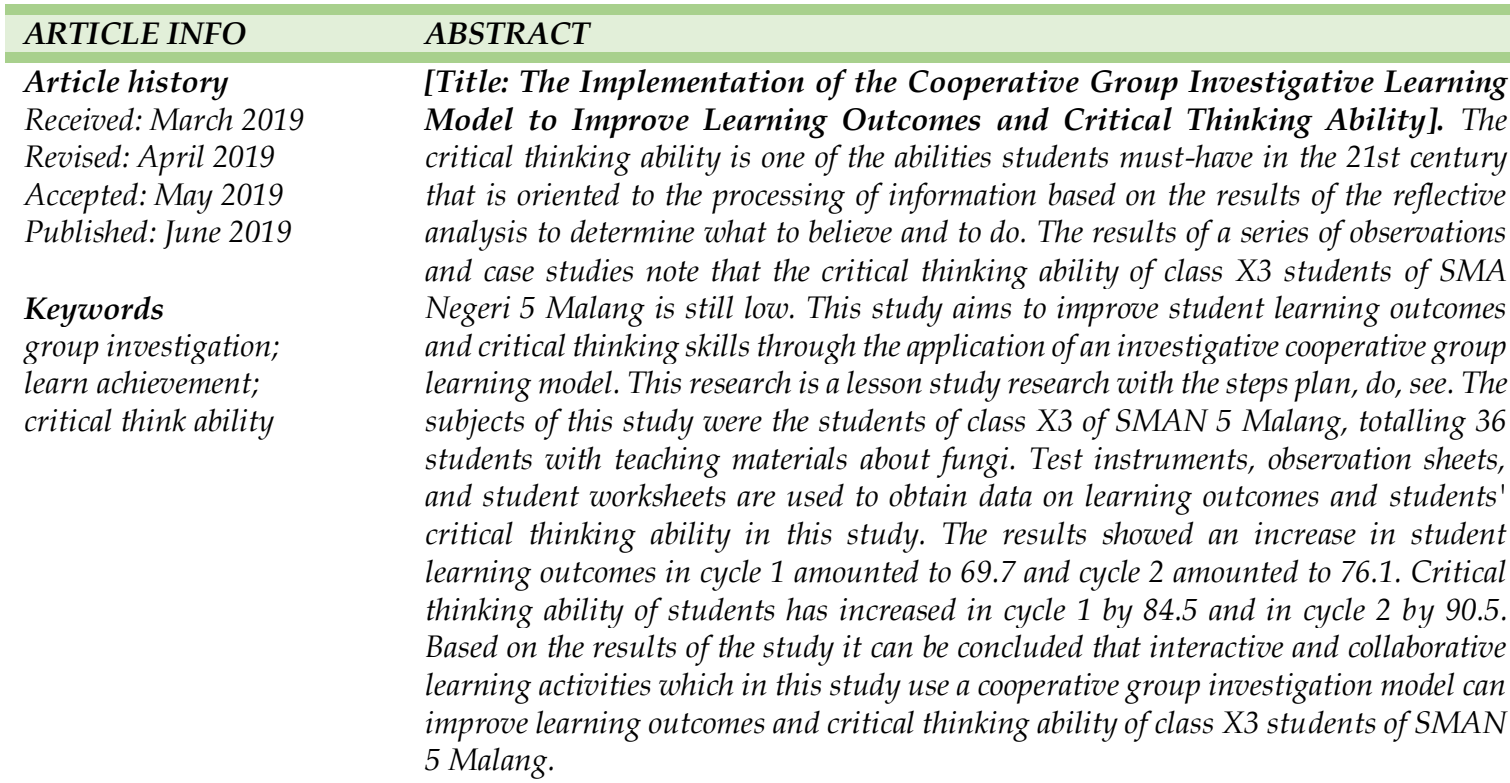

\section{INFO ARTIKEL}

Sejarah Artikel

Dikirim: Maret 2019

Direvisi: April 2019

Diterima: Mei 2019

Dipublikasi: Juni 2019

Kata kunci Grup investigasi; hasil belajar; kemampuan berpikir kritis

\begin{abstract}
ABSTRAK
Kemampuan berpikir kritis merupakan salah satu kemampuan yang harus dimilliki siswa di abad 21 yang berorientasi pada pemerosesan informasi berdasarkan hasil analisis yang reflektif untuk menentukan apa yang dipercayai dan dilakukan. Hasil serangkaian observasi dan studi kasus diketahui bahwa kemampuan berpikir kritis siswa kelas X3 SMA Negeri 5 Malang masih rendah. Penelitian ini bertujuan untuk meningkatkan hasil belajar dan kemampuan berpikir kritis siswa melalui penerapan model pembelajaran kooperatif grup investigasi. Penelitian ini merupakan penelitian lesson study dengan langkah-langkah plan, do, see. Subjek penelitian ini adalah siswa kelas X3 SMAN 5 Malang yang berjumlah 36 siswa dengan materi ajar tentang fungi. Intrumen tes, lembar observasi, dan lembar kerja siswa digunakan untuk mendapatkan data hasil belajar dan kemampuan berpikir kritis siswa dalam penelitian ini. Hasil penelitian menunjukkan adanya peningkatan hasil belajar siswa pada siklus 1 sebesar 69,7 dan siklus 2 sebesar 76,1 . Kemampuan berpikir kritis siswa mengalami peningkatan pada siklus 1 sebesar 84,5 dan pada siklus 2 sebesar 90,5. Berdasarkan hasil penelitian dapat
\end{abstract}


disimpulkan bahwa kegiatan pembelajaran yang interaktif dan kolaboratif yang dalam penelitian ini menggunakan model kooperatif grup investigasi mampu meningkatkan hasil belajar dan kemampuan berpikir kritis siswa kelas X3 SMAN 5 Malang.

How to Cite this Article? Pahrurozi. (2019). Penerapan Model Pembelajaran Kooperatif Group Investigasi untuk Meningkatkan Hasil Belajar dan Kemampuan Berpikir Kritis. Jurnal Penelitian dan Pengkajian Ilmu Pendidikan: e-Saintika, 2(2), 142-149.

\section{PENDAHULUAN}

Pembelajaran abad 21 membawa perubahan besar di semua bidang kehidupan, terutama di bidang ilmu pengetahuan dan teknologi informasi. Perubahan ini membawa dampak terhadap orientasi pendidikan di Indonesia. Bidang pendidikan melalui proses pembelajaran harus mampu menghasilkan sumber daya manusia abad 21 yang memiliki kemampuan berpikir (kreatif, kritis, mengambil keputusan dalam pembelajaran), kemampuan berkomunikasi dan berkolaborasi, penguasaan ilmu pengetahuan dan teknologi serta mandiri (Moeloek, 2010).

SMA Negeri 5 Malang di Jawa Timur merupakan salah satu sekolah yang menerapkan pembelajaran abad 21. Sekolah tersebut merupakan sekolah ungulan yang dapat dikategorikan sebagai sekolah yang dapat mencetak generasi muda yang sesuai dengan kriteria pembelajaran abad 21, namun berdasarkan hasil serangkaian observasi yang dilakukan, masih banyak ditemukan siswa yang belum memiliki kompetensi yang dibutuhkan untuk dapat berkontribusi dalam era modern saat ini. Kenyataan tersebut diperoleh berdasarkan hasil observasi di mana, pada tes tersebut siswa masih belum mampu menguraikan jawaban dengan benar, dan terkadang tidak sesuai dengan petunjuk soal sehingga berdampak pada hasil belajar dan kemampuan berpikir kritis siswa.

Kemampuan berpikir kritis merupakan salah satu tuntutan pendidikan abad 21 (Samsuri \& Firdaus, 2017) dan secara signifikan dapat dibelajarkan melalui pembelajaran berbasis masalah (Karmana, 2013; Meilani dkk., 2017; Armansyah dkk., 2018). Berpikir kritis merupakan serangkaian pemerosesan informasi berdasarkan hasil analisis yang reflektif untuk menentukan apa yang dipercayai dan dilakukan (Prayogi \& Asy'ari, 2013). Facione (2011) menjelaskan bahwa berpikir kritis merupakan keterampilan siswa dalam interpretasi, analisis, evaluasi, inferensi, eksplanasi, dan meregulasi pengetahuan yang dimiliki untuk memecahkan masalah.

Upaya yang dilakukan oleh guru untuk dapat meningkatkan hasil belajar dan kemempuan berpikir kritis siswa adalah dengan menerapkan model pembelajaran yang sesuai. Salah satu model pembelajaran yang dirasa efektif untuk dapat melatih kemampuan berpikir kritis siswa adalah strategi pembelajaran kooperatif (Susilo, 2007). Pada pembelajaran kooperatif siswa berdiskusi, berargumentasi, bertukar pikiran dan bekerja sama. Aktivias yang terjadi pada pembelajaran kooperatif merupakan aktivitas yang dapat mengembangkan hasil belajar (Muzaki dkk., 2015; Khotimah dkk., 2017; Sumiyati dkk., 2017) dan kemampuan berpikir kritis siswa (Samsuri dan Firdaus, 2017).

Salah satu strategi pembalajaran yang ada dalam model pembelajaran kooperatif adalah grup investigasi. Group investigasi adalah strategi pembelajaran 
yang mengelompokkan siswa menjadi beberapa kelompok kecil berdasarkan etnis dan latar belakang budaya yang berbeda. Siswa dalam kelompok tersebut ditugaskan untuk menganalisis, mensisntesis materi yang telah disampaikan oleh guru (Slavin, 2005). Setiap anggota kelompok harus memiliki kontribusi, harus ada pengaturan siapa yang mencari literature, siapa yang akan melakukan presentasi dan lain sebagainya. Guru di dalam kelas bertindak sebagai narasumber dan fasilitator. Guru juga memantau kegiatan kelompok siswa, memeriksa apakah mereka mengelola tugasnya, dan membantu setiap kesulitan yang mereka hadapi dalam interaksi kelompok. Penelitian ini bertujuan untuk meningkatkan hasil belajar dan kemampuan berpikir kritis siswa siswa kelas X3 SMA Negeri 5 Malang melalui penerapan model pembelajaran kooperatif grup investigasi.

\section{METODE}

Penelitian ini merupakan penelitian lesson study. Penelitian lesson study merupakan penelitian kolabrasi antara tim pengajar. Bertujuan untuk meningkatkan kuwalitas pembelajaran dan proses belajar mengajar di dalam kelas. Lesson study memfokuskan kinerja guru dalam upaya meningkatkan kwalitas pembelajaran secara berkelanjutan. Penerapan lesson study dalam penelitian ini dilakukan dalam dua siklus. Adapun tahapan - tahapan dalam lesson study adalah sebagai berikut.

1. Tahap Plan (Perencanaan).

Dalam peneilitian ini tahap plan dilaksanakan dengan mendiskusikan dan merancang RPP dengan tim. Melakukan konsultasi dengan guru mitra disekolah mengenai kondisi siswa dan sekolah. Serta meninjau kegiatan pembelajaran yang dilakukan oleh guru mitra untuk memperoleh gambaran umum mengenai proses belajar mengajar di SMAN 5 Malang. Tujuan dari tahap plan ini adalah untuk mengetahui kendala atau masalah yang dialami selama kegiatan belajar mengajar. Sehingga tim lesson study dapat memberikan solusi mengenai model pembelajaran untuk masalah tersebut.

2. Tahap Do ( Pelaksanaan ).

Dalam penelitian ini tahap do dilaksanakan dengan melakukan kegiatan belajar mengajar sesuai dengan hasil perencanaan pada tahap sebelumnya yaitu pada tahap plan. Dalam kegiatan pembelajaran yang dilaksanakan peneliti menggunkan model pembelajaran kooperatif group investigasi (GI), sesuai dengan hasil kesepakatan team teaching. Materi yang disampaikan dalam kegiatan penelitian ini adalah materi tentang fungi. Tahap ini juga dilaksankan dengan mengadakan observasi kegiatan belajar mengajar oleh tim lesson study dan guru mitra, melalaui lembar observasi.

3. Tahap See (Refleksi)

Dalam penelitian ini tahap see dilakukan dengan refleksi seluruh kegiatan belajar mengajar kemudian didiskusikan. Hasil refleksi diperoleh berdasarkan masukan dari tim dan guru mitra, dari hasil observasi, dan dari umpan balik siswa selama proses belajar mengajar. Kekurangan kegiatan pembelajaran pada tahap sebelumnya atau pada pertemuan sebelumnya kemudian didiskusikan dan diberikan solusi untuk dilaksanakan pada sisklus selanjutnya. Secara umum tahap 
pelaksanaan lesson study dalam penelitian ini dapat dilihat pada Gambar 1.

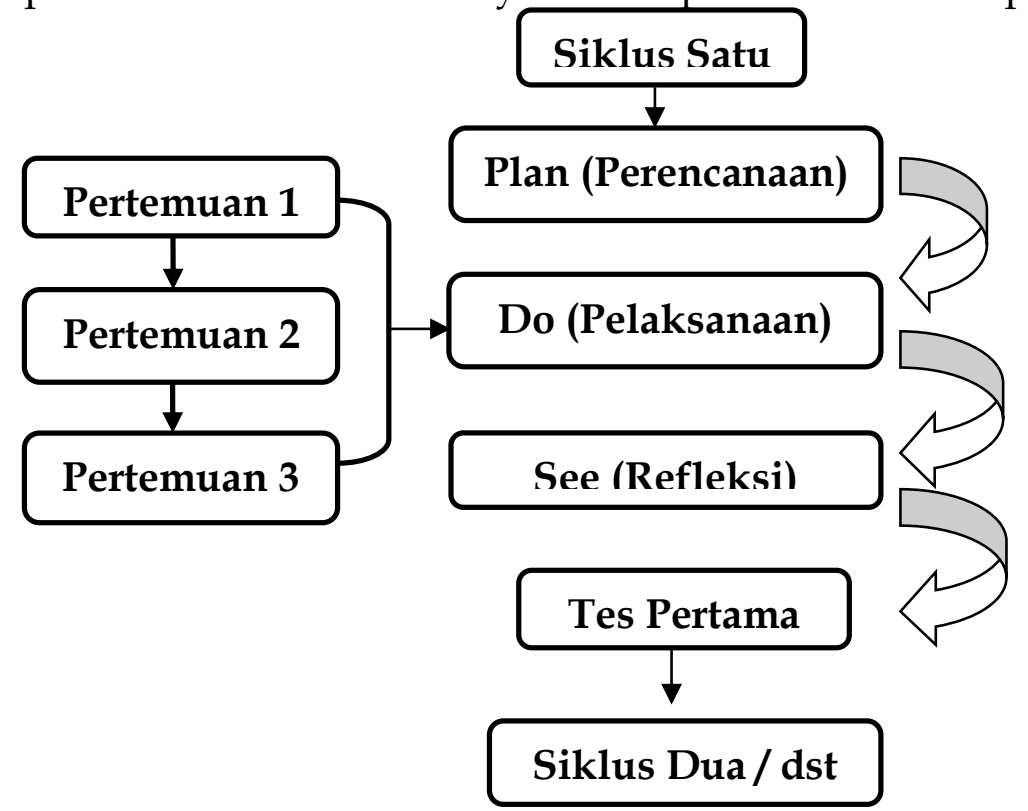

Gambar 1. Alur Penelitian Lesson Study (Susilo \& Laksono, 2007)

Berdasarkan Gambar 1 dapat diketahui alur dalam penelitian ini. Setiap pelaksanaan satu siklus peneliti dan team teaching harus melakukan langkahlangkah yang sesuai dengan gambar tersebut. Dengan mengikuti langkah tersebut peneliti dapat menganalisis hasil penelitian dalam masing-masing siklus. Dalam penelitian ini satu siklus dilakukan tiga atau empat kali pertemuan ditambah dengan ulangan harian dan remedy.

\section{Subjek Penelitian}

Objek dari penelitian ini adalah penerapan pembelajaran lesson study, dengan model pembelajaran kooperatif group investigasi (GI). Sedangkan materi yang dibahas dalam penelitian ini adalah materi mengenai fungi. Adapun subjek dalam penelitian ini adalah seluruh siswa kelas X3 di SMAN 5 Malang yang berjumlah 36 siswa. Dalam pelaksanaan penelitian ini, peneliti di bantu oleh team teaching sebanyak 4 orang. Materi yang diberikan dalam penelitian ini adalah materi tentang fungi.

\section{Sumber Data}

Data yang diperoleh dalam penelitian ini dibagi menjadi dua yaitu. Data kuantitatif yang diperoleh hasil tes siswa setiap akhir siklus, dan data kualitatif berupa hasil observasi. Selengkapnya data yang diperoleh dalan penelitian ini adalah sebagai berikut:

1. Tes (Ulangan Harian).

Dalam penelitian ini tes bertujuan untuk mengetahui hasil belajar siswa dengan menggunakan model pembelajaran kooperatif group investigasi (GI). Tes dilakukan setelah siswa memperoleh materi sebanyak dua sampai tiga kompetensi dasar.

2. Lembar Observasi.

Dalam penelitian lembar observsi bertujuan untuk memperoleh data mengenai keterlaksanaan pembelajaran atau ketuntasan pembelajaran dengan penerapan model pembelajaran kooperatif group invesigasi (GI). Data diperoleh dari lembar 
observasi yang di isi oleh tim lesson study dan guru mitra pada saat kegiatan belajar mengajar sedang berlangsung.

3. Lembar Kegiatan Siswa (LKS).

Dalam penelitian ini lembar kegiatan siswa bertujuan untuk mengetahui kemampuan berpikir kritis siswa, serta sebagai umpan balik siswa terhadap materi. Lembar kegiatan siswa dikerjakan setelah siswa memperoleh materi interaktif berupa video, materi bergambar, dan masalah yang sesuai dengan materi. Lembar kerja siswa juga diberikan kepada siswa pada saat melakukan pengamatan, misalnya pada salah satu pertemuan yang membahas mengenai licken. Siswa diminta untuk mengamati dan mengerjakan LKS secara berkelompok. Lembar kerja siswa dikerjakan bersama kelompok yang telah dibentuk sebelumnya. Hasil pengisian lembar kerja siswa akan dipresentasikan langsung oleh siswa dan siswa diberikan kesempatan untuk berdiskusi secara aktif diabawah bimbingan guru.

\section{Analisis Data}

Data kuantitatif diperoleh dari hasil ulangan harian siswa setelah selesai membahas satu kompetensi dasar. Data tersebut kemudian akan dianalisis dengan menggunakan rumus product moment, untuk mengetahui nilai rata - rata pada siklus tersebut. Hasil analisis siklus pertama tersebut kemudian akan dibandingkan dengan nilai rata-rata pada siklus selanjutnya, sehingga penelitian lesson study ini dianggap memiliki perkembangan yang berarti. Data kuantitatif tersebut juga dapat digunakan untuk mengetahui peningkatan hasil belajar maupun peningkatan kemampuan berpikir kritis siswa kelas X3 SMAN 5 Malang. Data kualitatif yang diperoleh dalam penelitian ini digunakan untuk mengetahui kemampuan kognitif (hasil belajar) dengan menggunakan model pembelajaran kooperatif Group Investigasi (GI). Data kualitatif diperoleh melalui lembar observasi yang diisi oleh guru mitra yang berjumlah 4 orang. Data kualitatif tersebut dapat digunakan untuk mengetahui kemampuan berpikir kritis siswa.

\section{HASIL DAN PEMBAHASAN}

Berdasarkan hasil penelitian yang dilakukan terhadap siswa kelas X3 SMAN 5 Malang, maka diperoleh beberapa data. Data hasil belajar siswa dengan menggunakan model pembelajaran kooperatif grup investigasi (GI) disajikan pada Tabel 1.

Tabel 1. Perbandingan Nilai Rata-Rata Hasil Belajar Siswa pada Siklus 1 dan Siklus 2.

\begin{tabular}{ccc}
\hline No & Siklus 1 & Siklus 2 \\
\hline 1 & 69,7 & 76,1 \\
\hline
\end{tabular}

Berdasarkan Tabel 1 dapat diketahui bahwa terjadi peningkatan hasil belajar siswa dari siklus 1 ke siklus 2. Peningkatan hasil belajar dalam penelitian ini dapat terjadi karena peneliti dan team teaching sangat fokus dalam penerapan model pembelajaran kooperatif group investigasi (GI). Dengan mengkondisikan kegiatan pembelajaran yang komunikatif dan kolaboratif siswa dapat lebih mudah memahami materi pelajaran. Sedangkan data kemampuan berpikir kritis siswa disajikan pada Tabel 2. 
Tabel 2. Perbandingan Nilai Rata-Rata Kemampuan Berpikir Kritis Siswa Pada Siklus 1 dan Siklus 2.

\begin{tabular}{ccc}
\hline No & Siklus 1 & Siklus 2 \\
\hline 1 & 84,5 & 90,5 \\
\hline
\end{tabular}

Berdasarkan Tabel 2 dapat diketahui bahwa terjadi peningkatan kemampuan berpikir kritis siswa. Kemampuan berpikir kritis siswa diketahui pada saat presentasi dan diskusi yang mengharuskan siswa untuk memberikan pendapat, menjawab, dan menyanggah pertanyaan dari siswa lain. Karena pembelajaran kooperatif lebih terfokus kepada siswa, sehingga memberikan lebih banyak kesempatan kepada siswa untuk menyatakan pendapat. Dalam penelitian ini siswa juga dibagi ke dalam beberapa kelompok kecil, sehingga memungkinkan siswa untuk berdiskusi dengan teman satu kelompok dan mempresentasikan hasilnya. Peneliti dan team teaching dalam setiap pertemuan berupaya untuk selalu merancang kegiatan pembelajaran yang inovatif. Misalnya dengan menghadirkan specimen jamur langsung ke dalam kelas, yang dijadikan sebagai objek pengamatan dan eksperimen oleh siswa. Salah satu kunci keberhasilan dalam penelitian ini juga tidak terlepas dari dukungan team teaching, yang selalu memberikan masukan-masukan yang membangun. Melakukan observasi dengan cermat, serta memberikan kinerja yang sesuai dengan tugas mereka masingmasing.

Pembelajaran kooperatif disinyalir dapat meningkatkan aktivitas belajar siswa (Ama \& Sartati, 2018; Pour dkk., 2018) melalui pembelajaran kelompok dan mandiri. Pembelajaran kooperatif grup investigasi dalam penelitian ini juga melalui proses-proses pembelajaran kelompok dalam pelaksanaannya sehingga dapat meningkatkan hasil belajar (Bobo, 2018) dan kemampuan berpikir kritis siswa (Samsuri \& Firdaus, 2017). Pernyataan tersebut sejalan dengan hasil penelitian Sriwahyuningsih dkk (2018) dan Lestari dkk (2017) yang menemukan bahwa pembelajaran kooperatif tipe make a match dengan permainan ranking one physical berpengaruh terhadap hasil belajar dan motivasi siswa. Motivasi dan aktivitas yang baik berdampak pada kemampuan berpikir kritis siswa. Hal tersebut terbukti dari peningkatan kemampuan berpikir kritis siswa pada siklus I dan siklus II. Sejalan dengan pernyataan tersebut, Samsuri dan Firdaus (2017) menyatakan pembelajaran kooperatif tipe STAD perpengaruh signifikan terhadap kemampuan berpikir kritis siswa.

\section{KESIMPULAN}

Berdasarkan hasil penelitian maka disimpulkan bahwa kegitan pembelajaran yang interaktif dan kolaboratif mampu meningkatakan hasil belajar dan kemampuan berpikir kritis siswa kelas X SMAN 5 Malang. Model pembelajaran kooperatif group investigasi (GI) lebih terfokus kepada kegiatan siswa, guru dalam kegiatan pembelajaran hanya sebagai fasilitator saja.

\section{SARAN}

Penerapan pembelajaran kooperatif tidak bisa diterapkan pada semua materi pelajaran biologi. Peneliti harus memilih materi yang membutuhkan pengamatan 
dan investigasi siswa, sehingga kegiatan belajar mengajar yang interaktif dan kolaboratif dapat terwujud. Bagi peneliti lain yang ingin melakukan penelitian yang sama, hendaknya memperhatikan ketersediaan alokasi waktu. Pembelajaran kooperatif harus menyediakan waktu kepada siswa untuk berdiskusi dan presentasi.

\section{DAFTAR PUSTAKA}

Ama, F.T \& Sartati, S.B. (2018). Meningkatkan Hasil Belajar Siswa dengan Model Snowball Throwing pada Pokok Bahasan Penyelesaian Pertidaksamaan Kuadrat. Jurnal Penelitian dan Pengkajian Ilmu Pendidikan: e-Saintika, 1(2), 73 80.

Armansyah, A., Ibrahim, M., \& Wasis, W. (2018). Pengembangan Perangkat Pembelajaran Fisika Menggunakan Model Siklus Belajar 5E untuk Melatihkan Kemampuan Berpikir Kritis. Prisma Sains : Jurnal Pengkajian Ilmu dan Pembelajaran Matematika dan IPA IKIP Mataram, 6(2), 56-65. doi:https:// doi.org/10.33394/j-ps.v6i2.967

Bobo, P., S. (2018). Implementasi Model Pembelajaran Think Pair Share untuk Meningkatkan Hasil Belajar Siswa. Jurnal Penelitian dan Pengkajian Ilmu Pendidikan: e-Saintika, 2(1), 49-54.

Dimyati \& Mudjiono. (1994). Belajar dan Pembelajaran. Jakarta: Proyek Pengembangan dan Peningkatan Mutu Tenaga Kependidikan.

Johnson, D. Johnson, R. \& Stanne, (2000). Cooperative Learning Methods: A MetaAnalysis. (Online), (http://www.clcrc.com/pages/cl-methods.html. diakses Juli 2009).

Karmana, I., W. (2013). Memberdayakan berpikir tingkat tinggi (higher order thinking) siswa SMA dalam pembelajaran biologi. Prisma Sains : Jurnal Pengkajian Ilmu dan Pembelajaran Matematika dan IPA IKIP Mataram, 1(1), 5666. doi:https:// doi.org/10.33394/j-ps.v1i1.519

Khotimah, H., Sumiyati \& Nurjannah. (2017). Pengaruh Teknik Pembelajaran Listening Team Terhadap Hasil Belajar IPS Siswa. Jurnal Penelitian dan Pengkajian Ilmu Pendidikan: e-Saintika, 1(1), 1-10.

Meilani, R., Hunaepi., \& Mirawati, B. (2017). Pengaruh Model Pembelajaran Berbasis Masalah dengan Pendekatan Saintifik terhadap Keterampilan Berpikir Kritis Siswa. Prisma Sains: Jurnal Pengkajian Ilmu dan Pembelajaran Matematika dan IPA IKIP Mataram, 5(1), 20-24.

Moeloek, F.A. (2010). Paradigma Pendidikan Nasional Abad XXI. Jakarta: Badan Standar Nasional Pendidikan Indonesia.Nasution, S. 1992. Berbagai Pendekatan dalam Proses Belajar dan Mengajar. Jakarta: PT. Bumi Aksara.

Muzaki, A., Purwanto., \& Karim, M.A. (2015). Problem-Based Learning melalui Belajar Kooperatif Think-Pair-Share untuk Meningkatkan Pemahaman Konsep Mahasiswa Calon Guru. Prisma Sains: Jurnal Pengkajian Ilmu dan Pembelajaran Matematika dan IPA IKIP Mataram, 3(2), 80-92.

Nurhadi, B., Y \& Senduk, A. G. (2004). Pembelajaran Kontekstual dan Penerapannya dalam KBK. Malang: UM

Pour, D., N., Herayanti, L., \& Sukroyanti, B., A. (2018). Pengaruh Model Pembelajaran Talking Stick terhadap Keaktifan Belajar Siswa. Jurnal Penelitian dan Pengkajian Ilmu Pendidikan: e-Saintika, 2(1), 36-40. 
Prayogi, S., \& Asy'ari, M. (2013). Implementasi model PBL (problem based learning) untuk meningkatkan hasil belajar dan kemampuan berpikir kritis siswa. Prisma Sains : Jurnal Pengkajian Ilmu dan Pembelajaran Matematika dan IPA IKIP Mataram, 1(1), 80-88. Retrieved from http://ojs.ikipmataram.ac.id/index.php/prismasains/article/view/521/ $\underline{485}$

Samsuri, T., \& Firdaus, L. (2017). Pengaruh Pembelajarn Kooperatif Student Teams Achivement Division (STAD) Terhadap Keteramilan Berpikir Kritis Siswa. Prisma Sains : Jurnal Pengkajian Ilmu dan Pembelajaran Matematika dan IPA IKIP Mataram, 5(1), 15-19. doi:https:// doi.org/10.33394/j-ps.v5i1.1110

Slavin, R. E. (1990). Cooperative Learning ( Teori, Riset dan Praktik). Bandung: Nusa Media.

Sriwahyuningsih, D., Ahzan, S., \& Habiburrahman, L. (2018). Pengaruh Model Pembelajaran Koperatif Tipe Make A Macth dengan Permainan Rangking One Physical Terhadap Motivasi dan Hasil Belajar Siswa. Jurnal Penelitian dan Pengkajian Ilmu Pendidikan: e-Saintika, 2(1), 29-35.

Sudjana, N. (1990). Penilaian Hasil Proses Belajar Mengajar. Bandung: PT. Remaja Rosdakarya.

Sumiyati., Nurjannah., \& Khotimah, H. (2017). Perbandingan Hasil Belajar IPS Terpadu Model Pembelajaran Kooperatif Tipe Two Stay-Two Stray Dengan Metode Ceramah. Jurnal Penelitian dan Pengkajian Ilmu Pendidikan: e-Saintika, 1(1), 33-44.

Susilo, H \& Laksono, K. (2007). Implementasi Penelitian Tindakan Kelas.(diunduh pada tanggal 12 Januari 2013).

Winarni, E. W. (2006). Pengaruh Strategi Pembelajaran terhadap Pemahaman Konsep IPA Biologi, Kemampuan Berpikir Kritis dan Sikap Ilmiah siswa kelas V SD dengan tingkat kemampuan akademik berbeda di Kota Bengkulu. Disertasi (Tidak diterbitkan). Malang. Program Pascasarjana Universitas Negeri Malang.

Winkell, W., S. (1999). Psikologi Pengajaran. Jakarta: Gramedia 